\title{
Osebne vrednote in zaupanje $v$ nacionalne institucije in institucije Evropske unije
}

UDK: 316.752:061(045)

\author{
Marjetica Primožič \\ Javna agencija za raziskovalno dejavnost Republike Slovenije \\ marjetka.primozic@guest.arnes.si
}

\section{Cene Bavec}

Univerza na Primorskem, Fakulteta za management Koper

cene.bavec@guest.arnes.si

\section{IZVLEČEK}

V prispevku je predstavljena raziskava medsebojnega vpliva osebnih vrednot državljanov članic EU27 in njihovega zaupanja v nacionalne institucije in institucije EU. Ovrgli smo hipotezo, da osebne vrednote, $z$ izjemo odnosa do demokracije in tolerance, vplivajo na omenjeno zaupanje. Le v okoljih, kjer je visoko vrednotena demokracija, je večje zaupanje $v$ nacionalne institucije, v tistih, kjer prevladuje solidarnost, pa je večje zaupanje $v$ institucije EU. Pokazalo pa se je, da obstaja statistično značilna razlika $v$ zaupanju $v$ institucije med državljani novih in starih članic EU27, kot tudi razlika v zaupanju v nacionalne institucije med državami z različnimi razredi pravnih sistemov. Nove članice imajo praviloma večje zaupanje $v$ institucije EU od povprečja in manjše zaupanje $v$ nacionalne institucije. Stare članice pa kažejo večinoma večje zaupanje $v$ nacionalne institucije in precej deljeno zaupanje $v$ institucije EU. Tudi značilnosti pravnega sistema $v$ posamezni članici EU vplivajo na zaupanje državljanov v nacionalne institucije, ne vplivajo pa na zaupanje $v$ institucije EU. Izrazito veliko zaupanje kažejo državljani držav iz skandinavskega pravnega kroga, medtem ko je zaupanje v nacionalne institucije $v$ postsocialističnih državah skoraj trikrat manjše.

Ključne besede: osebne vrednote, zaupanje, nacionalne institucije, institucije EU, nove članice EU27 


\section{Marjetica Primožič, Cene Bavec \\ Osebne vrednote in zaupanje $v$ nacionalne institucije in institucije Evropske unije}

\section{Uvod}

Veliko raziskav kaže na pomembne razlike $\vee$ odnosu državljanov posameznih evropskih držav ali regij do nacionalnih državnih institucij in do institucij Evropske unije (Kaase, 1999, McLaren, 2002, Evrobarometer, 2008). Posebej Evropska komisija redno spremlja in objavlja podobne raziskave, saj je to eden od pomembnih političnih kazalcev kohezivnosti in sprejemljivosti EU med državljani. Tudi njihove raziskave potrjujejo razlike med posameznimi regijami in državami, ki se z leti le malo spreminjajo. Na vprašanje, kje bi lahko bili vzroki za omenjene razlike, je mogočih veliko odgovorov, odvisno od zornega kota raziskovalcev in izbora spremenljivk, ki jih opazujemo (Hudson, 2006). Najpogosteje se omenjajo zgodovinske razlike in različne razvojne poti posameznih držav. To velja predvsem za nove članice EU, saj večina raziskav potrjuje, da obstajajo med novimi in starimi članicami razlike, ki se odražajo $v$ večini političnih, ekonomskih in socialnih kazalcev (Hofstede, 1998, Halman, 2001, Bavec, 2007). Veliko teh razlik lahko pripišemo neskladnosti v ekonomski razvitosti in tudi razvitosti političnega sistema, ki je $v$ večini novih članic še vedno $v$ izgradnji in še ni dosegel stabilnega stanja, ki je značilno za zahodnoevropske demokracije. Verjetno pa leži jedro vseh razlik $\vee$ ugotovitvi, ki jo je podal že Morgenthau (1995, str. 127), da zahodne nacionalne družbe kažejo navznoter večjo stopnjo socialne kohezije kot navzven. Stare članice EU se še vedno nagibajo $k$ tradicionalnemu gledanju na svoje nacionalne države, kar se odraža $v$ močni nacionalni zavesti in poudarjanju suverenosti, ki meji na samozadostnost. Nekatere nove članice so del tega zgodovinskega spomina izgubile $\vee$ političnih pretresih 20. stoletja, nekatere pa zgodovinskih izkušenj z lastno nacionalno državo niso nikoli niti imele.

V povezavi z novimi članicami EU27 iz Srednje Evrope in Baltika lahko povzamemo tudi ugotovitev, da je tranzicija $\vee$ tržno gospodarstvo in demokratični politični sistem zahodnega tipa pustila posledice tudi na posameznikih, kar pa bistveno vpliva na njihove osebne vrednote, percepcijo demokracije, pravnega sistema in posledično na zaupanje med nacionalnimi institucijami in institucijami EU. Osebne vrednote, ki so povezane z odnosom do soljudi in z moralnimi načeli, se med Evropejci le malo razlikujejo, razlike pa se pojavijo pri vrednotah, ki odražajo prej omenjene zgodovinske izkušnje. $V$ naši raziskavi se je pokazalo, da to velja predvsem za odnos do demokracije in medsebojne tolerance. 


\section{Marjetica Primožič, Cene Bavec \\ Osebne vrednote in zaupanje $v$ nacionalne institucije in institucije Evropske unije}

Raziskav, ki bi se spuščale $v$ povezavo osebnih vrednot in odnosa do institucij, skoraj ne poznamo (Hudson, 2006). Omeniti pa kaže sorodne raziskave povezane s socialnim kapitalom $\vee$ evropskih državah, ki ravno tako potrjujejo bistvene razlike med posameznimi regijami (van Schaik, 2002, Mihaylova, 2004, van Oorschot et al, 2005). Seveda pa socialni kapital le zelo posredno odraža osebne vrednote, zato smo izrabili priložnost, da je Evropska komisija objavila raziskavo o osebnih vrednotah državljanov v državah članicah EU (Evrobarometer, 2008). V naši raziskavi smo želeli preveriti predvsem povezavo med osebnimi vrednotami in zaupanjem državljanov članic EU $\vee$ nacionalne institucije (nacionalni pravni sistem, nacionalna vlada in nacionalni interes) v primerjavi z zaupanjem v institucije EU (EU kot politična tvorba, Evropski parlament in Evropska komisija). Zanimalo nas je tudi to, ali na omenjeno zaupanje vpliva tudi pravno okolje, $v$ katerem živijo. Pri tem smo izhajali iz predpostavke, da osebne vrednote in pravni sistem odražajo zgodovinske okoliščine, $v$ katerih so se razvijale posamezne države in $v$ katerih se je oblikoval odnos posameznikov do lastne države in $\vee$ zadnjem času do EU. Na ta način smo $v$ raziskavo posredno vključili tudi tezo, da je ta odnos odvisen tudi od zgodovinskih okoliščin.

Posebej pa kaže poudariti, da se $v$ raziskavi nismo spuščali v ekonomske vidike, saj v literaturi nismo našli dovolj prepričljivih kazalcev, ki bi napeljevali na sklep, da ekonomska razvitost posameznih držav neposredno vpliva na zaupanje državljanov $\vee$ nacionalne institucije in institucije EU. Res pa je, da trenutna finančna in posledično tudi socialna kriza odpira mnoga vprašanja povezana z zaupanjem $\vee$ državo nasploh ter še posebej $v$ Evropsko unijo. Kot kažejo trenutni dogodki na Islandiji in delno $v$ Irski, lahko po koncu ekonomske krize pričakujemo tudi opazne spremembe $v$ odnosu posameznih držav in regij do Evropske unije kot politične institucije in kot politične ideje.

\section{Cilji raziskave in raziskovalna metodologija}

\subsection{Raziskovalne hipoteze}

$\checkmark$ raziskavi smo s kvantitativnimi metodami osvetlili in analizirali razlike med socialnimi vrednotami in zaupanjem državljanov $v$ nacionalne institucije in institucije EU. Analizirali smo tudi vpliv pravnih sistemov, ki so značilni za posamezno državo, na zaupanje državljanov $\vee$ te institucije. Raziskava je temeljila na sekundarnih podatkih pridobljenih iz virov EU, saj bi vsaka primarna raziskava 
Marjetica Primožič, Cene Bavec

Osebne vrednote in zaupanje $v$ nacionalne institucije

in institucije Evropske unije

presegla materialne možnosti vključenih raziskovalcev. Po drugi strani pa imamo na razpolago veliko podatkov na ravni $\mathrm{EU}$ in posameznih članic, ki so zbrani na osnovi enotnih metodologij in zato omogočajo objektivno primerljivost med državami. Vsi uporabljeni podatki so bili objavljeni v Evrobarometru 69.

Kot osnovni cilj raziskave smo si postavili iskanje objektivnih podatkov in meril, s katerimi bi lahko potrdili ali ovrgli raziskovalne hipoteze, ki so bile postavljene predvsem na osnovi indicev, ki smo jih zasledili $v$ posameznih raziskavah in tudi na osnovi splošno sprejetih domnev, ki jih je sprejela tako politika kot stroka. Omejili smo se na tri hipoteze, ki jih je bilo mogoče statistično potrditi ali ovreči:

Hipoteza 1: Osebne vrednote državljanov članic EU vplivajo na zaupanje v nacionalne institucije in $v$ institucije EU.

Hipoteza 2: Med starimi in novimi članicami EU obstajajo značilne razlike v zaupanju njihovih državljanov tako $v$ nacionalne institucije kot $v$ institucije EU.

Hipoteza 3: Značilnosti pravnega sistema v posamezni članici EU vplivajo na zaupanje državljanov $\vee$ nacionalne institucije in $\vee$ institucije EU.

Prva hipoteza odraža v uvodu omenjeno domnevo, da so zgodovinske okoliščine, ki se odražajo tudi $v$ osebnih vrednotah posameznikov, eden od vzrokov za razlike $v$ odnosu državljanov do nacionalnih institucij in institucij EU. $\checkmark$ hipotezi seveda nismo govorili o zgodovini, saj jo $v$ našem modelu nismo mogli objektivno opredeliti in statistično obdelati. Zato smo se osredotočili neposredno na osebne vrednote. Druga hipoteza sloni na domnevi, da obstajajo bistvene razlike predvsem med skupinama novih in starih članic EU27. Razlika med novimi in starimi članicami je pogosto omenjena, čeprav je razmeroma malo kvantitativnih raziskav, ki bi to dejstvo potrjevale, predvsem pa nudile podrobnejše razlage. Poudariti pa kaže, da se nove članice EU delijo v dve zelo različni skupini, ki se razlikujeta po večini ekonomskih in socialnih kazalcev. Na eni strani sta to Ciper in Malta, na drugi pa ostalih deset postsocialističnih držav. Tretja hipoteza pa odraža razmeroma razširjeno prepričanje, da so razlike $\vee$ odnosu do nacionalnih institucij in institucij EU tudi posledica različnih pravnih sistemov. $V$ tej zvezi se navaja predvsem Velika Britanija, ki v svojem evroskepticizmu bistveno odstopa od drugih držav, ter skandinavske države, ki so po drugi strani izrazito naklonjene ideji Evropske unije. Glede na to, da podobne raziskave $v$ literaturi nismo zasledili, se nam je zdela ta hipoteza še posebej zanimiva. 


\subsection{Uporabljeni podatki in potek raziskave}

Osebne vrednote, ki smo jih uporabili $v$ raziskavi, so definirane z 12 spremenljivkami (Tabela 1), ki so bile povzete iz rednih statističnih raziskavah EU (Evrobarometer, 2008). Razlog, da smo se odločili ravno za te osebne vrednote, je seveda $\vee$ tem, da so ti podatki statistično obdelani in javno dostopni. Osebne vrednote so za vsako državo posebej predstavljene $v$ intervalu od 0 do 1. Večja kot je ta vrednost, večji pomen dajejo državljani določene države posamezni osebni vrednoti.

Tabela 1: Osebne vrednote državljanov članic EU, ki smo jih upoštevali v raziskavi

\begin{tabular}{|c|c|c|}
\hline $\begin{array}{l}\text { Številka } \\
\text { vprašanja }\end{array}$ & Vprašanje v Eurobarometru & Osebne vrednote državljanov EU \\
\hline 1. & QD2 & mir \\
\hline 2. & QD2 & človekove pravice \\
\hline 3. & QD2 & spoštovanje človeškega življenja \\
\hline 4. & QD2 & demokracija \\
\hline 5. & QD2 & osebna svoboda \\
\hline 6. & QD2 & vladavina prava \\
\hline 7. & QD2 & enakost \\
\hline 8. & QD2 & toleranca \\
\hline 9. & QD2 & solidarnost \\
\hline 10. & QD2 & samoizpolnitev \\
\hline 11. & QD2 & spoštovanje drugih kultur \\
\hline 12. & QD2 & religija \\
\hline
\end{tabular}

Vir: Evropska komisija, Evrobarometer 69, 2008

Podobno velja tudi za podatke o zaupanju državljanov $\vee$ nacionalne institucije in $\vee$ institucije EU (Tabela 2). Tudi $v$ tem primeru leži stopnja zaupanja državljanov $v$ intervalu od 0 do 1 in je izračunana za vsako državo članico EU posebej. 
Marjetica Primožič, Cene Bavec

Osebne vrednote in zaupanje $v$ nacionalne institucije

in institucije Evropske unije

Tabela 2: Zaupanje $v$ institucije, ki smo jih upoštevali v raziskavi

\begin{tabular}{|c|c|c|}
\hline $\begin{array}{l}\text { Številka } \\
\text { vprašanja }\end{array}$ & Vprašanje v Eurobarometru & Zaupanje državljanov EU \\
\hline 1. & QA12.5 & zaupanje v nacionalni pravni sistem \\
2. & OA12.9 & zaupanje v nacionalno vlado \\
3. & QA12.10 & zaupanje v nacionalni parlament \\
4. & QA12.11 & zaupanje v EU \\
5. & QA18.1 & zaupanje v Evropski parlament \\
6. & QA18.2 & zaupanje v Evropsko komisijo \\
\hline
\end{tabular}

Vir: Evropska komisija, Evrobarometer 69, 2008

Raziskava je torej temeljila na dveh skupinah sekundarnih informacijskih virov na ravni posameznih držav članic EU, ki so zbrani na osnovi identičnih metodologij in zato povsem primerljivi med državami in na ravni EU.

Kot smo omenili, je bil osnovni cilj raziskave predvsem uporaba kvantitativnih metod, ki naj bi dale čim bolj objektivno sliko trenutnega stanja $\vee$ EU. Zato smo uporabili vrsto statističnih metod vrednotenja medsebojnih razmerij in soodvisnosti med obravnavanimi kazalci. Posebej kaže poudariti, da smo konstrukte, kot so osebne vrednote in zaupanje v institucije, opisovali z večjim številom parametrov, kar je vodilo $v$ zahtevnejše multivariantne statistične analize. Nismo pa se spuščali v podrobnejšo interpretacijo rezultatov, saj smo ugotovili, da bi z osebno interpretacijo pravzaprav zameglili ali celo zgrešili osnovni cilj raziskave, to je največja možna objektivnost v okviru razpoložljivih podatkov.

\section{Predstavitev rezultatov}

\subsection{Grupiranje držav glede na osebne vrednote}

V prvem koraku smo ugotavljali, ali se članice EU kakorkoli grupirajo glede na osebne vrednote njihovih državljanov. Če bi namreč opazili grupiranje držav s podobnimi vrednotami državljanov, bi lahko preverili, ali so te skupine kakor koli podobne skupinam držav, razvrščenim glede na njihov odnos do nacionalnih in institucij EU. S tem bi lahko sklepali na medsebojno soodvisnost dveh večparametrskih spremenljivk, kot so osebne vrednote in zaupanje. $V$ tem delu raziskave smo 


\section{Marjetica Primožič, Cene Bavec \\ Osebne vrednote in zaupanje v nacionalne institucije in institucije Evropske unije}

uporabili hierarhično analizo grup (hierarchical cluster analysis), s katero lahko grupiramo vzorce, ki so opisani z večjim številom spremenljivk. $V$ našem primeru je bilo to 12 različnih osebnih vrednot za vsako članico EU. Razlog, da smo kot matematično orodje vzeli prav analizo grup, leži tudi v tem, da je ta analiza usmerjena $v$ vzorce ( $v$ našem primeru države) in manj $v$ parametre ( $v$ našem primeru posamezne osebne vrednote), kot je to $v$ primeru večine drugih statističnih metod. Hierarhična analiza grup tudi nudi enostavno vizualno interpretacijo podobnosti vzorcev (držav), kot je razvidno iz Slike 1. Poudariti kaže tudi to, da so osebne vrednote med seboj funkcijsko skoraj neodvisne, kar potrjuje, da so bile $v$ raziskavi Eurobarometra skrbno in metodološko ustrezno izbrane. Kljub temu pa opazimo med nekaterimi spremenljivkami nekaj statistično značilnih korelacij, ki so lahko pomembne pri končni interpretaciji rezultatov. Negativna je korelacija med vrednotama vladavina prava in solidarnost $(R=-0,673, p<0,01)$. Negativna je tudi korelacija med vrednotama religija in toleranca $(R=-0,608, p<0,01)$. Posebej je zanimiva negativna korelacija med vrednotama samoizpolnjevanje in človekove pravice $(R=-0,523, p<0,01)$.

\section{Slika 2: Dendrogram razvrstitve držav članic EU glede na osebne vrednote njihovih državljanov}

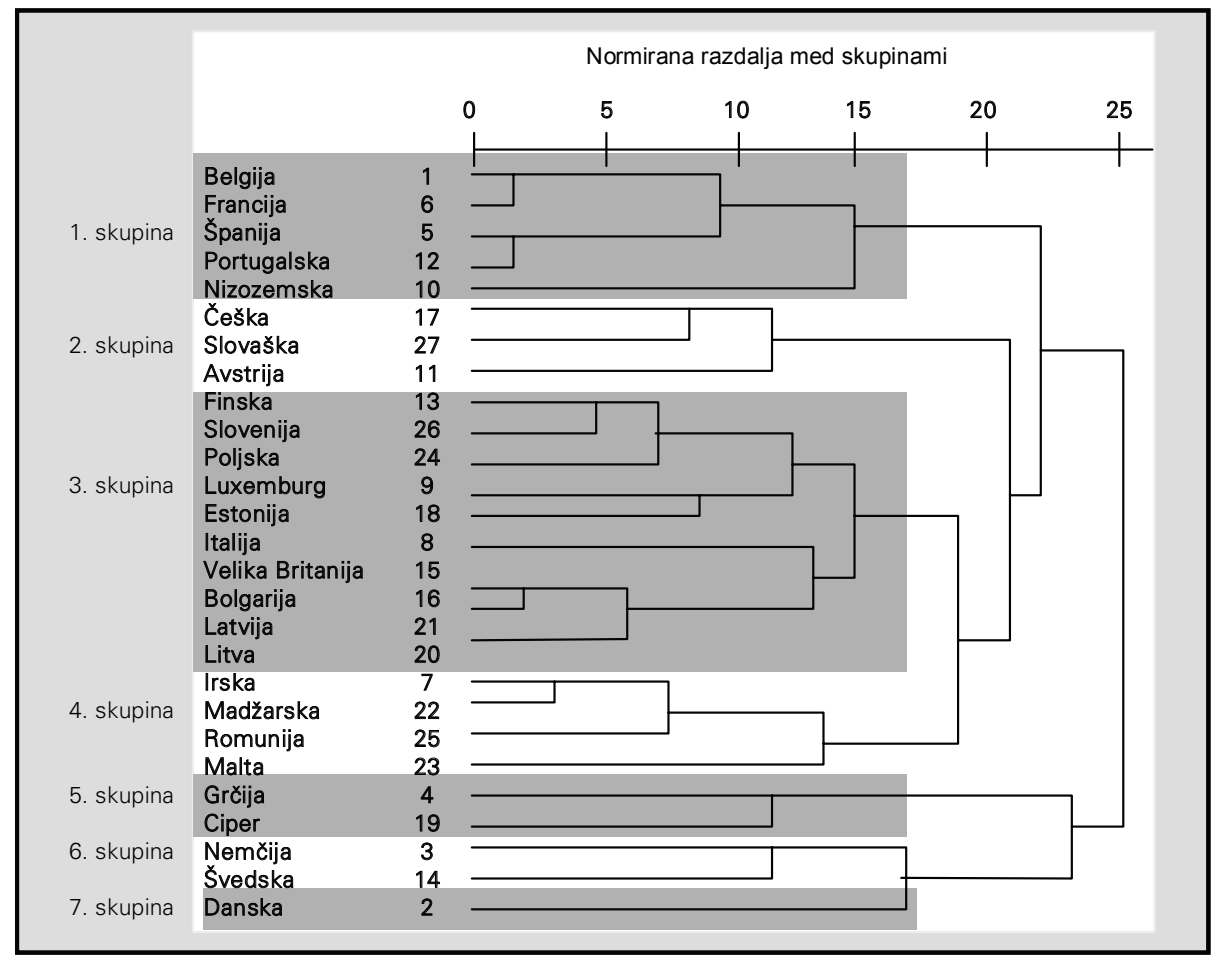


Marjetica Primožič, Cene Bavec

Osebne vrednote in zaupanje $v$ nacionalne institucije

in institucije Evropske unije

Iz slike 1 vidimo, katere države so si najbolj podobne po osebnih vrednotah državljanov. Slika ne govori niti o vrstnem redu, niti o posameznih vrednotah. Kaže samo, kako so si države podobne glede na vseh 12 osebnih vrednot istočasno. Če gremo na sliki z leve strani na desno, vidimo, katere države so si najbolj podobne in kako se države postopoma združujejo $\checkmark$ večje in večje skupine (podobne so si države, ki so $v$ isti hierarhiji). Kot ponazoritev vzemimo samo prve štiri države $\vee$ prvi skupini. Vidimo, da se $\vee$ hierarhiji paroma najprej združita Belgija in Francija ter Španija in Portugalska. Manjša kot je normirana razdalja združevanja, večja je podobnost med državama. Očitno so si osebne vrednote državljanov Belgije in Francije izredno podobne. Podobno velja tudi za Španijo in Portugalsko, kar je na neki način logično, saj so si države podobne tudi po drugih kriterijih, da ne govorimo o geografski bližini. Pri veliko bolj grobi delitvi, na primer pri normirani razdalji 9 pa se obe skupini združita $\vee$ eno, ki se razlikuje od vseh drugih. Enaka logika velja tudi za vse druge države prikazane $v$ dendrogramu na sliki 1.

$\checkmark$ raziskavi smo končno grupiranje skupin držav opravili pri normirani razdalji 17. Tako smo dobili sedem izrazito različnih skupin držav glede na osebne vrednote njihovih državljanov. Grupiranje brez dvoma kaže na to, da osebne vrednote državljanov niso enake $v$ vseh državah in da niso slučajnostno porazdeljene po teritoriju EU. $V$ prvi skupini vidimo samo stare članice EU (Belgija, Francija, Španija, Portugalska in Nizozemska), v drugi tri sosednje srednjeevropske države (Češka, Slovaška in Avstrija), v največji tretji pa že mešanico starih in novih članic (Slovenija, Finska, Poljska, Estonija, Luksemburg, Italija, Velika Britanija, Bolgarija, Litva, Latvija). V četrti skupini so poleg Irske nove članice EU (Irska, Madžarska, Romunija, Malta), $\checkmark$ peti Grčija in Ciper, v šesti Nemčija in Švedska, v sedmi pa samo Danska, ki je tako različna, da sama tvori svojo skupino. Ker je tretja skupina zelo velika, jo lahko delimo še naprej (npr. pri normirani razdalji 10). V tem primeru bi ta skupina razpadla $\vee$ štiri podskupine, ki so si med seboj še posebej podobne: prvo podskupino tvorijo Slovenija, Finska in Poljska, drugo Estonija in Luxemburg, tretjo Italija in Velika Britanija, četrto pa Bolgarija, Litva in Latvija. Kot vidimo, je od nas odvisno, kako daleč drobimo ali agregiramo grupe držav. 


\subsection{Grupiranje držav glede na zaupanje $v$ nacionalne institucije in institucije EU}

Če po isti metodologiji razvrstimo članice EU še glede na zaupanje njihovih državljanov $v$ nacionalne institucije in institucije EU (zaupanje $v$ tri nacionalne in tri institucije EU), dobimo že na prvi pogled precej drugačne skupine držav (slika 2), kar nakazuje, da osebne vrednote niso povezane z omenjenim zaupanjem.

Slika 2: Razvrstitev držav članic EU glede na njihovo zaupanje v nacionalne institucije in institucije EU

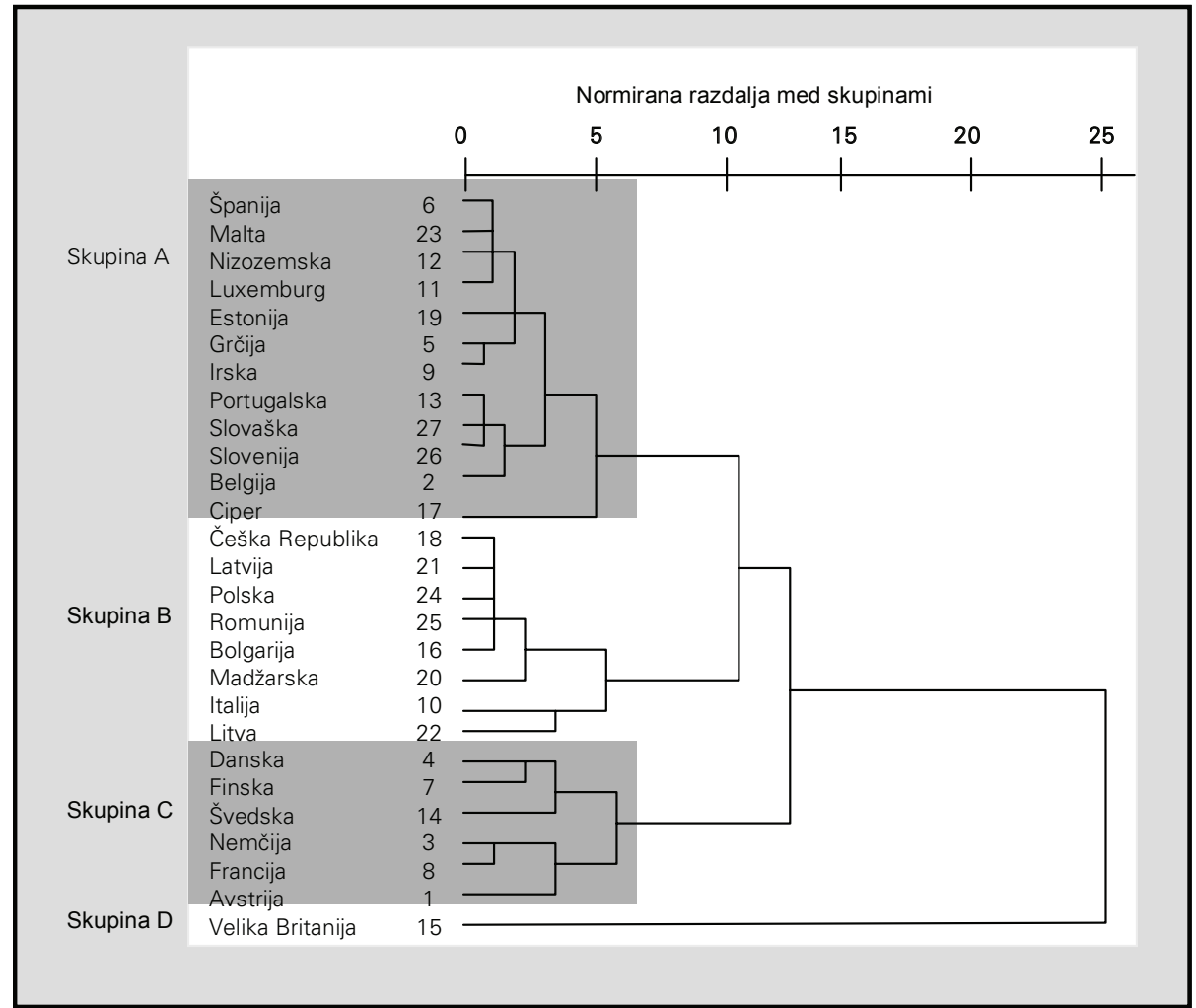

Pri normirani razdalji 7 dobimo štiri skupine držav. Mimogrede, pri normirani razdalji 4 bi dobili sedem skupin, vendar bi bila $\vee$ dveh skupinah le po ena država. Zato smo se odločili za nekoliko bolj grobo razvrščanje. Kot vidimo iz slike 2, izrazito izstopa Velika Britanija, ki tvori povsem svojo skupino, ki se bistveno razlikuje od vseh ostalih (celo pri normirani razdalji 25). Zanimiva je tudi skupina C, ki združuje najbolj razvite stare članice EU (Danska, Finska, 
Marjetica Primožič, Cene Bavec

Osebne vrednote in zaupanje $v$ nacionalne institucije in institucije Evropske unije

Švedska, Nemčija, Francija in Avstrija) in kaže, da je njihovo zaupanje do nacionalnih institucij in institucij EU zelo podobno. Skupina B pa po drugi strani povezuje nove članice (Češka, Latvija, Poljska, Romunija, Bolgarija, Madžarska in Litva) in Italijo v skupino z zelo podobno stopnjo zaupanja. Medtem pa skupina A združuje zelo pestro skupino novih in starih članic (Španija, Malta, Nizozemska, Luxemburg, Estonija, Grčija, Irska, Portugalska, Slovaška Slovenija, Bolgarija in Ciper). Vendar podrobnejša analiza omenjene skupine na primer kaže, da izstopa Ciper, ki je svoja skupina, preostale države pa se grupirajo vsaj v dve ločeni skupini pri normirani razdalji 3.

Skupine držav na sliki 2 se izrazito razlikujejo od skupin na sliki 1, kar kaže, da osebne vrednote državljanov na splošno ne vplivajo bistveno na njihovo zaupanje v nacionalne in v institucije EU. Na primer, Nemčija, Francija in Avstrija so si po zaupanju $v$ nacionalne in EU institucije zelo podobne (slika 2), medtem ko so z zornega kota osebnih vrednot zelo različne, saj vse spadajo $v$ različne skupine (slika 1). Ugotovitev, da osebne vrednote niso povezane z zaupanjem $v$ institucije, potrjujejo tudi bivariantne korelacije med tema dvema skupinama spremenljivk, ki so praktično vse statistično neznačilne. Vseeno pa med njimi opazimo dve statistično značilni soodvisnosti. Pozitivna je namreč korelacija med povprečnim občutkom za demokracijo kot osebno vrednoto ter zaupanjem $v$ nacionalne institucije $(R=0,621, p<0,01)$, medtem, ko je korelacija z zaupanjem v institucije EU statistično neznačilna. Ravno tako je pozitivna korelacija med povprečnim občutkom za solidarnost ter zaupanjem $\vee$ institucije EU, ki je sicer majhna vendar statistično značina $(R=0,401, p<0,05)$, medtem ko je korelacija z zaupanjem $v$ nacionalne institucije statistično neznačilna. To pomeni, da večinsko osebne vrednote ne vplivajo na zaupanje $v$ nacionalne institucije in v institucije EU, vendar pa obstajata omenjeni izjemi, ki ju kaže posebej poudariti.

Faktorska analiza spremenljivk, ki določajo zaupanje $v$ nacionalne institucije in institucije EU, je pokazala, da se vseh šest spremenljivk enolično porazdeli po dveh faktorjih, zato lahko z veliko statistično natančnostjo vpeljemo dve povsem novi spremenljivki, ki lahko paroma zamenjata vse druge spremenljivke (tabela 2). Dve novi agregatni spremenljivki sta:

1. povprečno (agregatno) zaupanje $v$ domače institucije;

2. povprečno (agregatno) zaupanje $v$ institucije EU.

Vpeljava dveh novih agregatnih spremenljivk (koloni 2 in 3 v tabeli 3) omogoča lažjo interpretacijo in razumevanje rezultatov ter njihov grafični prikaz. Mimogrede, $v$ tabeli 3 je dodana tudi klasifikacija glede na značilni tip pravnih sistemov, $v$ katero spada posamezna država, vendar bomo te podatke analizirali $\vee$ naslednjem podpoglavju. 
Marjetica Primožič, Cene Bavec

Osebne vrednote in zaupanje $v$ nacionalne institucije in institucije Evropske unije

Tabela 3: Povprečno (agregatno) zaupanje v institucije po posameznih državah

\begin{tabular}{|c|c|c|c|}
\hline Država & $\begin{array}{l}\text { Povprečno zaupanje v } \\
\text { nacionalne institucije }\end{array}$ & $\begin{array}{l}\text { Povprečno zaupanje } \\
\quad \text { v institucije EU }\end{array}$ & Tip pravnih sistemov \\
\hline (1) & (2) & (3) & (4) \\
\hline Avstrija & 0,54 & 0,38 & nemški \\
\hline Belgija & 0,46 & 0,67 & romanski \\
\hline Bolgarija & 0,14 & 0,55 & postsocialistične države \\
\hline Ciper & 0,66 & 0,66 & nemški \\
\hline Češka & 0,23 & 0,55 & postsocialistične države \\
\hline Danska & 0,71 & 0,55 & skandinavski \\
\hline Estonija & 0,50 & 0,59 & postsocialistične države \\
\hline Finska & 0,69 & 0,50 & skandinavski \\
\hline Francija & 0,36 & 0,46 & romanski \\
\hline Grčija & 0,44 & 0,59 & nemški \\
\hline Irska & 0,45 & 0,57 & anglo-ameriški \\
\hline Italija & 0,21 & 0,46 & romanski \\
\hline Latvija & 0,19 & 0,54 & postsocialistične države \\
\hline Litva & 0,18 & 0,39 & postsocialistične države \\
\hline Luksemburg & 0,54 & 0,54 & romanski \\
\hline Madžarska & 0,22 & 0,54 & postsocialistične države \\
\hline Malta & 0,54 & 0,60 & anglo-ameriški \\
\hline Nemčija & 0,45 & 0,43 & nemški \\
\hline Nizozemska & 0,57 & 0,59 & skandinavski \\
\hline Poljska & 0,25 & 0,54 & postsocialistične države \\
\hline Portugalska & 0,36 & 0,61 & nemški \\
\hline Romunija & 0,25 & 0,56 & postsocialistične države \\
\hline Slovaška & 0,34 & 0,64 & postsocialistične države \\
\hline Slovenija & 0,30 & 0,60 & postsocialistične države \\
\hline Španija & 0,55 & 0,61 & romanski \\
\hline Švedska & 0,57 & 0,47 & skandinavski \\
\hline Velika Britanija & 0,33 & 0,25 & anglo-ameriški \\
\hline
\end{tabular}

Vir: Avtor (na osnovi izračuna iz podatkov Eurobarometra) 
Marjetica Primožič, Cene Bavec

Osebne vrednote in zaupanje $v$ nacionalne institucije

in institucije Evropske unije

Na sliki 3 je grafični prikaz agregatnih zaupanj $v$ nacionalne institucije in $v$ institucije EU po posameznih državah. Notranji koordinatni sistem (delitev $\vee$ štiri kvadrante) je postavljen tako, da osi potekata skozi povprečno zaupanje $\vee$ nacionalne institucije na ravni EU $(0,41)$ in skozi povprečno zaupanje $v$ institucije EU $(0,53)$, kot je predstavljeno $v$ tabeli 4 . Vidimo različno porazdelitev novih in starih članic. Nove članice imajo praviloma večje zaupanje $\vee$ institucije EU od EU povprečja in manjše zaupanje $\vee$ nacionalne institucije. Stare članice pa kažejo večinsko večje zaupanje $\vee$ nacionalne institucije in precej deljeno zaupanje $v$ institucije EU. Izstopa predvsem Velika Britanija z izrazito majhnim zaupanjem $\vee$ institucije EU in tudi podpovprečnim zaupanjem $\vee$ nacionalne institucije. Opozoriti kaže tudi na izjemno nizko zaupanje Italijanov $\vee$ nacionalne institucije in razmeroma veliko zaupanje $\vee$ nacionalne institucije prebivalcev Cipra in Malte, ki je izrazito večje od drugih novih članic. To potrjuje našo ugotovitev, da se $s$ tega zornega kota nove članice pravzaprav delijo $v$ dve skupini, Ciper in Malto ter postsocialistične države.

\section{Slika 3: Porazdelitev novih in starih članic EU glede na zaupanje $v$ nacionalne institucije in institucije EU}

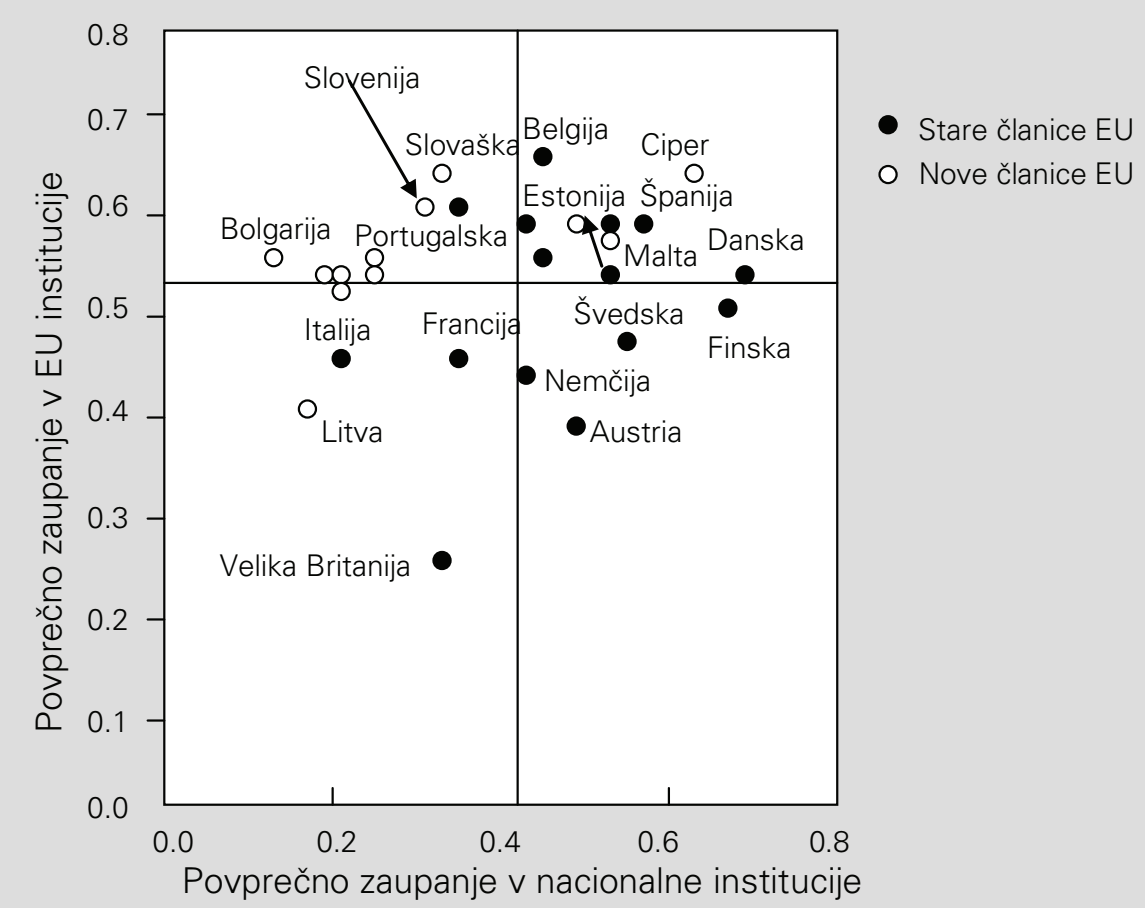




\section{Marjetica Primožič, Cene Bavec \\ Osebne vrednote in zaupanje $v$ nacionalne institucije in institucije Evropske unije}

Kot vidimo, je Slovenija blizu preostalim novim srednjeevropskim in baltskim novim članicam, čeprav kaže nekoliko večje zaupanje $v$ nacionalne institucije kot večina drugih. Če odštejemo Ciper in Slovaško, izražajo Slovenci od vseh novih članic tudi največje zaupanje $v$ institucije EU, ki je na ravni Estonije in Malte.

Izrazito grupiranje novih članic kaže na določene zakonitosti, ki so povezane tudi z njihovo bližnjo preteklostjo in vstopanjem v EU. Ena od interpretacij je ta, da je prilagajanje pravnemu redu EU in skoraj avtomatično prevzemanje direktiv EU pravzaprav postavilo nacionalne institucije $v$ drugorazreden položaj, kar se je odrazilo tudi na zaupanje državljanov, ki so imeli občutek, da so institucije EU zanesljivejše in tudi bolj demokratične. Druga razlaga pa pravi, da je odnos do teh institucij odvisen tudi od značilnosti pravnega sistema $\vee$ posamezni državi. $\checkmark$ uvodu smo podali nekaj razlag in Morgenthauov pogled na zahodnoevropske nacionalne države. Zato smo $v$ tretji raziskovalni hipotezi predpostavili, da značilnosti pravnega sistema $\vee$ posamezni državi vplivajo na odnos državljanov do nacionalnih institucij in tudi do institucij EU. Da bi preverili to predpostavko, smo članice EU grupirali tudi po tipih pravnih sistemov, ki najbolj odražajo značilnosti njihove pravne ureditve (Arminjon, at al, 1952, Zweigert in Kötz, 1998, Grasmann, 1998):
1. skandinavski tip pravnih sistemov
2. francoski tip pravnih sistemov
3. nemški tip pravnih sistemov
4. anglo-ameriški (Common Law)
5. tip postsocialitičnih držav

Poudariti kaže, da omenjene delitve niso povsem črno-bele, saj smo bili v določenih primerih $v$ dilemi, kam uvrstiti posamezno državo, zato lahko govorimo le o prevladujočih značilnostih pravnih sistemov $\vee$ posamezni državi. Postsocialističnih držav namenoma nismo razvrstiti po trenutno veljavnih pravnih sistemih, saj predpostavljamo, da na zaupanje večine državljanov še vedno bolj vplivajo zgodovinski refleksi, kot pa trenutni pravni sistem, ki je $\vee$ večini primerov še $v$ izgradnji. 
Marjetica Primožič, Cene Bavec

Osebne vrednote in zaupanje $v$ nacionalne institucije

in institucije Evropske unije

Tabela 4: Povprečno zaupanje v institucije

\begin{tabular}{|l|c|c|}
\hline & $\begin{array}{c}\text { Povprečno zaupanje v } \\
\text { nacionalne institucije }\end{array}$ & $\begin{array}{c}\text { Povprečno zaupanje } \\
\text { v institucije EU }\end{array}$ \\
\hline Povprečje EU & 0,41 & 0,53 \\
Povprečje v starih članicah & 0,48 & 0,51 \\
Povprečje v novih članicah & 0,32 & 0,56 \\
\hline \multicolumn{1}{|c|}{ Tipi pravnih sistemov: } & & 0,53 \\
\hline Skandinavski & 0,64 & 0,57 \\
Nemški & 0,49 & 0,47 \\
Anglo-ameriški (Common Law) & 0,44 & 0,55 \\
Romanski & 0,42 & 0,55 \\
Postsocialistične države & 0,26 & \\
\hline
\end{tabular}

Vir: Avtor

Rezultati kažejo, da se povprečne vrednosti zaupanja v nacionalne institucije in institucije EU statistično značilno razlikujejo le pri zaupanju v nacionalne institucije, kjer kažejo izrazito veliko zaupanje države iz skandinavskega pravnega kroga $(0,64)$, medtem ko je zaupanje $v$ nacionalne institucije $\vee$ postsocialističnih državah skoraj trikrat manjše $(0,26)$. Teh razlik pa ne opazimo pri zaupanju $\vee$ institucije EU, ki so sicer prisotne v intervalu od 0,47 do 0,57, vendar jih večina ni statistično značilnih, zato o objektivnih razlikah ne moremo govoriti.

Zanimivo je tudi to, da statistični enosmerni ANOVA test pokaže, da osebne vrednote nimajo povezave s pravnimi sistemi, razen odnosa do demokracije, ki kaže, da je različen $v$ različnih pravnih sistemih $(F=5,29, p=0,004)$. Demokracija najvišje kotira kot osebna vrednota $\vee$ anglo-ameriškem $(0,38)$ ter nemškem pravnem sistemu $(0,31)$, najnižja pa je $\vee$ postsocialističnih državah $(0,20)$.

\subsection{Potrjevanje raziskovalnih hipotez}

Že vizualna primerjava razvrstitve držav glede na osebne vrednote državljanov (slika 1) in glede na njihovo zaupanje $v$ nacionalne institucije in institucije EU (slika 2) kaže, da se skupine držav ne prekrivajo, kar pomeni, da med njimi ni povezave. Tudi izračun korelacij med posameznimi osebnimi vredno- 


\section{Marjetica Primožič, Cene Bavec \\ Osebne vrednote in zaupanje $v$ nacionalne institucije in institucije Evropske unije}

tami in obema agregatnima indeksoma (tabela 3) kaže, da obstajajo statistično značilne korelacije le med dvema spremenljivkama, med drugimi pa ne. To pomeni, da velika večina osebnih vrednot ne vpliva na zaupanje državljanov v nacionalne institucije in $v$ institucije $\mathrm{EU}$, s čimer smo zavrnili prvo raziskovalno hipotezo, ki je predvidevala, da obstajajo statistično značilne razlike.

Povprečno agregatno zaupanje $v$ nacionalne institucije je $v$ starih članicah EU enako 0,48, $v$ novih pa le 0,32 (tabela 4). Podobno velja tudi za razliko $v$ zaupanju $\vee$ institucije EU, kjer pa je razlika manj izrazita. $V$ starih članicah je povprečje $0,51 \vee$ novih pa 0,56 . Poudariti pa kaže, da je zaupanje $\vee$ starih članicah zelo razpršeno, zato povprečna vednost ne odraža zelo objektivne slike. Na eni strani imamo namreč izrazite evroskeptike (npr. Velika Britanija in Avstrija), na drugi pa izrazite privržence ideji EU (npr. Belgija, Portugalska in Španija). Medtem ko je zaupanje $v$ institucije EU $v$ novih članicah skoraj enako. Razlike so dobro vidne tudi iz slike 3. Vse omenjene razlike so statistično značilne, s tem pa smo potrdili drugo hipotezo, ki je predvidevala, da obstajajo razlike med starimi in novimi članicami EU $\vee$ zaupanju državljanov $\vee$ nacionalne institucije in v institucije EU.

Tretja hipoteza je delno potrjena in delno zavrnjena. Potrjen je prvi del hipoteze, ki je predvideval, da značilnosti pravnega sistema $\vee$ posamezni članici EU vplivajo na zaupanje državljanov v nacionalne institucije, zavrnjen pa je drugi del hipoteze, ki je predvideval, da značilnosti pravnega sistema vplivajo tudi na zaupanje $\vee$ institucije EU. Poudariti kaže, da smo pri ocenjevanju te hipoteze vzeli vse postsocialistične države kot eno skupino, ki je nismo razdeljevali po trenutni značilnosti njihovih pravnih sistemov. Če bi poskušali deliti še te države, bi se pokazalo, da jih je večina v nemških pravnih sistemih, ena ali dve pa sta $\vee$ skandinavskih pravnih sistemih. Vendar bi bila interpretacija rezultatov $\checkmark$ tem primeru zelo problematična, saj bi pomešali stare in nove članice EU, kjer pa imajo državljani iz že omenjenih zgodovinskih razlogov zelo različno percepcijo nacionalnih institucij.

\section{Zaključek}

Kot je dejal že Morgenthau (1995), so ljudje v določenem času dojemljivi le za določene ideje z ozirom na okoliščine, $v$ katerih živijo. To seveda velja tudi za prebivalce držav članic EU, ki oblikujejo svoj odnos do nacionalne države in do Evropske unije, pač glede na svoje okolje in probleme s katerimi se soočajo. Zato je razumevanje njihovega zaupanja $v$ nacionalne institucije in institucije EU 
Marjetica Primožič, Cene Bavec

Osebne vrednote in zaupanje $v$ nacionalne institucije

in institucije Evropske unije

posredno tudi razumevanje okoliščin, v katerih živijo. Analiza grupiranja držav, glede na osebne vrednote in zaupanja $\vee$ institucije je po eni strani potrdila nekatere znane predpostavke in ugotovitve, hkrati pa je razkrila tudi nekaj manj vidnih dejstev.

Kot smo poudarili pri opisovanju raziskovalnih hipotez, so bile vse tri na videz sprejemljive in so na določen način odražale širše razumevanje obravnavane problematike. Naša raziskava pa je pokazala, da so hipoteze le delno potrjene, kar pomeni, da nekatere stvari niso take, kot se zdijo na prvi pogled. Prva ugotovitev, ki sledi iz raziskave, je nepovezanost med osebnimi vrednotami in zaupanjem $v$ institucije, tako nacionalne kot EU. Edini osebni vrednoti, ki sta povezani z omenjenim zaupanjem, sta demokracija in solidarnost. $V$ okoljih, kjer je demokracija visoko vrednotena, je večje tudi zaupanje $v$ nacionalne institucije, $v$ okoljih, kjer je visoko vrednotena solidarnost, pa je večje zaupanje $\checkmark$ institucije EU. Ne da bi se spuščali $v$ podrobnejše razlage, lahko ugotovimo, da Evropejcem Evropska unija ne deluje posebej demokratično, pomeni pa jim solidarnost.

Ker osebne vrednote večinoma niso povezane z zaupanjem $v$ institucije, ležijo vzroki za različno zaupanje nekje drugje. Po naši raziskavi leži eden od razlogov $\vee$ sami zgodovini in posledično $v$ tipu pravnega sistema $\vee$ posamezni državi, saj se je pokazalo, da je zaupanje $\vee$ nacionalne institucije izrazito veliko $v$ državah s skandinavskim pravnim sistemom, izrazito majhno pa je $v$ postsocialističnih državah. Zaupanje državljanov $\vee$ nacionalne institucije $\vee$ drugih treh pravnih sistemih (nemški, anglo-ameriški in romanski) je precej podobno in $v$ bistvu predstavlja evropsko povprečje.

Raziskava je tudi potrdila dejstvo, ki je $v$ javnosti in politiki več ali manj intuitivno sprejeto, da državljani novih in starih članic EU nimajo enakega zaupanja niti $\vee$ nacionalne institucije niti $\vee$ institucije EU. Državljani starih članic kažejo značilno večje zaupanje $\vee$ nacionalne institucije, medtem ko državljani novih članic bolj zaupajo institucijam EU. Ta ugotovitev potrjuje domnevo, da demokracije z daljšo tradicijo zbujajo zaupanje svojih državljanov in obratno. Ljudje se $v$ starih članicah EU težje odpovedujejo državnim atributom na račun institucij EU, kot v novih članicah, čeprav je ideja EU nastala pri njih. $V$ raziskavi se nismo spuščali $\vee$ to področje, vendar pa nekateri kazalci kažejo, da vlada med državljani starih članic precejšnje nezaupanje $v$ novih članic, kar dodatno obremenjuje njihov odnos do razširjene EU. Podobne raziskave, ki so bile narejene pred petnajstimi ali dvajsetimi leti, namreč kažejo na bistveno večjo homogenost 


\section{Marjetica Primožič, Cene Bavec \\ Osebne vrednote in zaupanje $v$ nacionalne institucije in institucije Evropske unije}

takratnih članic in tudi bistveno večji občutek pripadnosti takratnim evropskim integracijam.

Po drugi strani pa je zanimiva ugotovitev, da je zaupanje državljanov starih članic $v$ institucije EU zelo deljeno in se razteza od popolnega nezaupanja do izrazito velikega zaupanja. Očitno obstajajo v teh okoljih še drugi razlogi, ki oblikujejo odnos državljanov do Evropske unije. Delno smo to pojasnili z različnimi značilnostmi pravnih sistemov $\vee$ posamezni državi, $\vee$ glavnem pa ostaja to vprašanje odprto in tudi ni bilo predmet naše raziskave. $V$ raziskavi se namenoma nismo spuščali $\vee$ podrobnejšo interpretacijo rezultatov in to prepuščamo strokovnjakom s posameznih področij. Želeli smo predstaviti le podatke in statistično dokazljive medsebojne povezave, ki bi omogočale čim bolj objektivno interpretacijo z različnih zornih kotov.

Marjetica Primožič je zaposlena v sektorju za analize Javne agencije za raziskovalno dejavnost Republike Slovenije. Pred tem je na agenciji vodila oddelek za mednarodno sodelovanje ter pokrivala bilateralno sodelovanje z 20 državami. V prejšnjih resornih ministrstvih za znanost in tehnologijo je sodelovala predvsem pri pripravi mednarodnih državnih in medministrskih sporazumov ter urejala strokovne in promocijske publikacije ministrstev.

Dr. Cene Bavec je kot izredni profesor managementa in znanstveni svetnik redno zaposlen na Fakulteti za management Koper Univerze na Primorskem. Bil je tudi dekan Visoke šole za management, državni sekretar za tehnologije ter namestnik direktorja takratnega Zavoda RS za statistiko. Njegov osnovni akademski interes so predvsem organizacijske vede in menedžment informacijskih tehnologij. 


\section{Marjetica Primožič, Cene Bavec \\ Osebne vrednote in zaupanje $v$ nacionalne institucije in institucije Evropske unije}

\section{Literatura}

- Adam, F., Roncevic, B. (2005). Social Capital: Recent Debates and Research Trends, Social Science Information, 42(2), 155-183.

- Anderson, J. J. (ed) (1999). Regional Integration and Democracy, Rowman \& Littlefield.

- Arminjon, P., Nolde, B., Wolff, M. (1952). Traité de droit comparé, T. III, Revue internationale de droit comparé, Volume 4, Issue 1, str. 166-167.

- Bavec, C. (2007). Interdependence between social values and national performance indicators: the case of the enlarged European Union. Managing global transitions, vol. 5, no. 2, str. 213-228.

- Grasmann, D. (1998). Uvod v velike pravne sisteme, Prva knjiga, Cankarjeva založba, Ljubljana.

- Halman, L. (2001). The European Values Study: a Third Wave: Source Book of the 1999/2000 European Values Study Survey, Tilburg University, http://www2.warwick .ac.uk/ fac/soc/wbs/conf/olkc/archive/olkc1/papers/512_lam.pdf.

- Hofstede, G. (1998). Attitudes, Values and Organizational Culture: Disentangling the Concepts, Organization Studies, Vol. 19, No. 3, str. 477-493.

- Hudson, J. (2006). Institutional Trust and Subjective Well-Being across the EU, Kyklos, Vol. 59, No. 1, str. 43-62.

- Kaase, M. (1999). Interpersonal trust, political trust and non-institutionalised political participation in Western Europe, West European Politics, vol. 22, no. 3, str. 1 - 21.

- McLaren, L. M. (2002). Public Support for the European Union: Cost/Benefit Analysis or Perceived Cultural Threat?, The Journal of Politics, Cambridge University Press.

- Mihaylova, D. (2004). Social Capital in Central and Eastern Europe. A Critical Assesment and Literature Riview. Budapest: Center for Policy Studies at the Central European University.

- Morgenthau, H. (1995). Politika med narodi, DZS, Ljubljana.

- Newton, K. (2001). Trust, Social Capital, Civil Society, and Democracy, International Political Science Review, Vol. 22, No. 2, 201-214.

- Oorschot van, W., Arts, W. (2005). The Social Capital of European Welfare States - The Crowding out Hypothesis Revisited. Journal of European Social Policy. 15 (1). 5-26.

- Patrick, F., Zabojnik, J. (2005) Trust as Social Capital and the Process of Economic Development. Journal of the European Economic Association. 3 (1). 51-94.

- Schaik van, Ton. (2002). Social Capital in the European Values Study Surveys. Tilburg: Tilburg University. Netherlands. http://www.oecd.org/dataoecd/22/22/2381883.pdf.

- Zweigert, K., Kötz, H. (1998). An Introduction to Comparative Law, Clarendon Press; 3 edition.

- (2008). Evrobarometer 69, European Commission, Brussels. 